\title{
PERILAKU IBU HAMIL TENTANG ANTENATAL CARE DI PUSKESMAS BAHU KECAMATAN MALALAYANG KOTA MANADO
}

\author{
${ }^{1}$ Erly Melisa Ompusunggu \\ ${ }^{2}$ Iyone E.T. Siagian \\ ${ }^{2}$ J. M. L. Umboh
}

\author{
${ }^{1}$ Kandidat Skripsi Fakultas Kedokteran Universitas Sam Ratulangi Manado \\ ${ }^{2}$ Bagian Ilmu Kesehatan Masyarakat Fakultas Kedokteran \\ Universitas Sam Ratulangi Manado \\ Email: early_luvpa2jc@yahoo.co.id
}

\begin{abstract}
Problem of maternal mortality is still a major problem in the health field. Until now, Maternal Mortality Rate (MMR) in Indonesia is still quite high according to the results of the Household Health Survey (NHHS) in 2009 which is 421 per 100,000 live births. The main causes of maternal deaths are haemorrhage, infection and pre / eclampsia. Knowledge of Antenatal Care of pregnant women is critical because it can help reduce maternal and infant mortality. Examination of pregnancy (Antenatal Care $=$ ANC) can be used as a means to motivate pregnat women to health professionals. This study aims to get an idea of the knowledge, attitudes and actions of expectant mothers about antenatal care. Research carried out by using the descriptive survey method. The population in this study were all pregnant women are checked throughout pregnancy in the health center's shoulders with the sample is the entire population. The results showed $46 \%$ of respondents who know how many times should do prenatal care during pregnancy, $46 \%$ of respondents who do not know how many times should do prenatal care during pregnancy and $8 \%$ of respondents who do not know how many times should do prenatal care during pregnancy. As many as $92 \%$ of respondents agreed with every pregnant woman should consult her pregnancy at least $\geq 4$ times during pregnancy, $8 \%$ of respondents did not agree with every pregnant woman should consult her pregnancy at least $\geq 4$ times during pregnancy. as many as $62 \%$ of respondents routinely perform pregnancy checks to health care during pregnancy, $38 \%$ of respondents did not routinely perform pregnancy checks to health services during pregnancy. Conclusion: From these results, it can be seen that the knowledge, attitudes, and actions of expectant mothers to antenatal care is good enough. This shows knowledge of prenatal care during pregnancy affect pregnant women, pregnant women have a readiness to act, although the examination of action kehamialan respondents is quite high, but not all do such a complete prenatal care in accordance with existing rules. Recommended for health authorities to conduct outreach to the community about the importance of prenatal care conducted in accordance with the age of her pregnancy in an effort to reduce maternal mortality.
\end{abstract}

Keywords : The behavior of pregnat women, antenatal care

\footnotetext{
Abstrak: Masalah kematian ibu hamil masih merupakan masalah utama dalam bidang kesehatan. Sampai saat ini Angka Kematian Ibu (AKI) di Indonesia masih cukup tinggi sesuai hasil Survei Kesehatan Rumah Tangga (SKRT) tahun 2009 yaitu 421 per 100.000 kelahiran hidup. Penyebab utama kematian ibu adalah perdarahan, infeksi dan pre/eklampsia. Pengetahuan ibu hamil tentang Antenatal Care sangat penting karena akan dapat membantu mengurangi angka kematian ibu dan bayi. Pemeriksaan kehamilan (Antenatal Care $=$ ANC) dapat dijadikan sebagai sarana untuk memotivasi ibu hamil agar bersalin ke tenaga kesehatan. Penelitian ini bertujuan untuk mendapatkan gambaran pengetahuan, sikap dan tindakan ibu
} 
hamil tentang antenatal care. Penelitian yang dilakukan bersifat deskriptif dengan menggunakan metode survei. Populasi dalam penelitian ini adalah seluruh ibu hamil yang memeriksakan kehamilannya di Puskesmas Bahu dengan sampel adalah seluruh populasi. Hasil penelitian menunjukan sebanyak $46 \%$ responden yang tahu berapa kali seharusnya melakukan pemeriksaan kehamilan selama hamil, 46\% responden yang kurang tahu berapa kali seharusnya melakukan pemeriksaan kehamilan selama hamil dan $8 \%$ responden yang tidak tahu berapa kali seharusnya melakukan pemeriksaan kehamilan selama hamil. Sebanyak 92\% responden setuju dengan setiap ibu hamil harus memeriksakan kehamilannya sekurangkurangnya $\geq 4$ kali selama kehamilan, $8 \%$ responden tidak setuju dengan setiap ibu hamil harus memeriksakan kehamilannya sekurang-kurangnya $\geq 4$ kali selama kehamilan. sebanyak $62 \%$ responden rutin melakukan pemeriksaan kehamilan ke pelayanan kesehatan selama hamil, 38\% responden tidak rutin melakukan pemeriksaan kehamilan ke pelayanan kesehatan selama hamil. Simpulan: Dari hasil penelitian tersebut, dapat dilihat bahwa pengetahuan, sikap, dan tindakan ibu hamil terhadap pemeriksaan antenatal care sudah cukup baik. Hal ini menunjukan pengetahuan tentang pemeriksaan kehamilan mempengaruhi ibu hamil selama kehamilannya, ibu hamil mempunyai kesiapan untuk bertindak, meskipun tindakan pemeriksaan kehamilan responden cukup tinggi, namun tidak seluruhnya melakukan pemeriksaan kehamilan tersebut secara lengkap sesuai dengan aturan yang ada. Disarankan bagi dinas kesehatan untuk mengadakan penyuluhan kepada masyarakat tentang pentingnya dilakukan pemeriksaan kehamilan sesuai dengan umur kehamilannya sebagai upaya menurunkan angka kematian ibu.

Kata Kunci : Perilaku Ibu Hamil, Antenatal Care

Di Indonesia masalah kematian ibu masih merupakan masalah utama dalam bidang kesehatan. Sampai saat ini Angka Kematian Ibu (AKI) di Indonesia masih cukup tinggi sesuai hasil Survei Kesehatan Rumah Tangga (SKRT) tahun 2009 yaitu 421 per 100.000 kelahiran hidup. Penyebab utama kematian ibu adalah perdarahan, infeksi dan pre/eklampsia. ${ }^{1}$

Di wilayah Propinsi Sulawesi Utara, angka kematian ibu saat melahirkan tahun 2010 sebesar 69 per 100.000 kelahiran hidup sedangkan angka kematian bayi sebesar 281 per 100.000 kelahiran hidup. Sehubungan dengan ini kiranya ibu hamil selalu menjaga kesehatannya agar bayi yang dikandung dan dilahirkan nantinya sehat dengan rutin melakukan antenatal care yaitu K1 dan K4. ${ }^{3}$ Dipuskesmas Bahu sendiri cakupan $\mathrm{K} 1$ dan K4 berdasarkan rekapan PWS-KIA Dinas Kesehatan Kota Manado tahun 2010 adalah K1 82,10\%, dan K4 74,66\%. Persentasi ini meningkat bila dibandingkan tahun 2009 adalah K1 $72,26 \%$ dan K4 62,10\%. ${ }^{2}$

Salah satu upaya untuk meningkatkan persalinan yang aman adalah dengan melakukan pemeriksaan rutin. Periksa ulang satu kali sebulan sampai kehamilan tujuh bulan, periksa ulang dua kali sampai kehamilan sembilan bulan, periksa ulang setiap minggu sesudah kehamilan sembilan bulan, periksa khusus bila ada keluhankeluhan. ${ }^{3}$

Kemampuan pelayananan kesehatan suatu negara ditentukan dengan perbandingan tinggi rendahnya angka kematian ibu dan angka kematian perinatal. Dikemukakan bahwa angka kematian perinatal lebih mencerminkan kesanggupan suatu negara untuk memberikan pelayanan kesehatan. ${ }^{4}$

Pemeriksaan kehamilan yang teratur akan menurunkan bukan saja angka kematian ibu hamil, ibu bersalin dan nifas tetapi juga menurunkan angka kecacatan bayi di Indonesia. Berdasarkan latar belakang di atas hal inilah yang mendorong penulis untuk melakukan penelitian dengan judul 'Perilaku Ibu Hamil Tentang Antenatal Care di Puskesmas Bahu Kecamatan Malalayang Kota Manado.

\section{METODE PENELITIAN}

Penelitian ini dilakukan dengan cara deskriptif (metode survei) yang berlokasi di 
Puskesmas Bahu Kecamatan Malalayang Kota Manado. Waktu pelaksanaan Penelitian pada bulan November-Desember 2011. Populasi dalam penelitian ini adalah seluruh ibu hamil yang memeriksakan kehamilannya di Puskesmas Bahu, sedangkan sampelnya adalah semua populasi. Pengumpulan data dilakukan melalui kuesioner yang dibagikan pada setiap ibu hamil yang melakukan pemeriksaan kehamilan di puskesmas Bahu. Dan diolah dengan menggunakan sistem tabulasi dan analisa berdasarkan hasil persentasi.

Variabel penelitian ini terdiri dari: 1) Karakteristik Responden; Nama, Umur, Tempat tinggal, Pendidikan, Jumlah anak, Umur kehamilan, 2) Pengetahuan tentang (Manfaat antenatal care, Jadwal antenatal care, Pelayanan antenatal care), 3) Sikap; ibu hamil memeriksakan kehamilannya, terhadap pelayanan kesehatan, 4) Tindakan; Melakukan pemeriksaan rutin kehamilan, Melakukan kunjungan pemeriksaan.

Pada penelitian ini, data yang diperoleh diolah dalam bentuk penyajian data yang diuraikan dalam bentuk kalimat, tetapi untuk melihat perilaku ibu hamil yang terdiri dari pengetahuan, sikap, dan tindakan ibu hamil terhadap pemeriksaan Antenatal Care di puskemas Bahu Kecamatan Malalayang Kota Manado, maka penyajian data juga dibuat dalam bentuk Tabel sebagai berikut:

\section{HASIL}

\section{Pengetahuan}

Tabel 1. Distribusi responden yang tahu manfaat memeriksakan kehamilan ke pelayanan kesehatan.

\begin{tabular}{cccc}
\hline No. & Keterangan & $\mathbf{N}$ & $\mathbf{\%}$ \\
\hline 1 & Tahu & 50 & 100 \\
2 & Kurang tahu & 0 & 0 \\
3 & Tidak tahu & 0 & 0 \\
\hline & Jumlah & 50 & 100 \\
\hline
\end{tabular}

Berdasarkan tabel satu, didapatkan yang tahu manfaat memeriksakan kehamilan $100 \%$.
Pada tabel dua, sebanyak $70 \%$ responden yang melakukan pemeriksaan kehamilan pertama pada trimester I, 30\% responden yang melakukan pemeriksaan kehamilan pertama pada trimester II dan $0 \%$ responden yang melakukan pemeriksaan kehamilan pertama pada trimester III.

Tabel 2. Distribusi responden berdasarkan pertama kali melakukan pemeriksaan kehamilan.

\begin{tabular}{cccc}
\hline No. & Keterangan & $\mathbf{N}$ & $\mathbf{\%}$ \\
\hline 1 & $\begin{array}{c}\text { Trimester I } \\
(1-3 \text { bulan) }\end{array}$ & 36 & 70 \\
2 & $\begin{array}{c}\text { Trimester II } \\
(4-6 \text { bulan) } \\
\text { Trimester III } \\
\text { (7-9 bulan) }\end{array}$ & 15 & 30 \\
3 & Jumlah & 50 & 0 \\
\hline
\end{tabular}

Tabel 3. Distribusi responden berdasarkan kepada siapa sebaiknya melakukan pemeriksaan kehamilan.

\begin{tabular}{cccc}
\hline No. & Keterangan & N & \% \\
\hline 1 & Dokter SpOg/Dokter & 27 & 54 \\
2 & Umum & 23 & 46 \\
3 & Bidan & 0 & 0 \\
& Perawat Bidan & & \\
\hline & Jumlah & 50 & 100 \\
\hline
\end{tabular}

Berdasarkan tabel tiga, Sebanyak 54\% responden melakukan pemeriksaan kehamilan pada dokter $\mathrm{SpOg} /$ Dokter umum, $46 \%$ responden melakukan pemeriksaan kehamilan pada bidan dan $0 \%$ responden melakukan pemeriksaan kehamilan pada perawat bidan.

Tabel 4. Distribusi responden berdasarkan tahu berapa kali seharusnya melakukan pemeriksaan kehamilan selama hamil.

\begin{tabular}{cccc}
\hline No. & Keterangan & N & \% \\
\hline 1 & Tahu $(\geq 4$ kali & 23 & 46 \\
2 & Kurang Tahu $(<4$ & 23 & 46 \\
3 & kali) & 4 & 8 \\
& Tidak tahu & & \\
\hline & Jumlah & 50 & 100 \\
\hline
\end{tabular}


Berdasarkan tabel empat, sebanyak $46 \%$ responden yang tahu berapa kali seharusnya melakukan pemeriksaan kehamilan selama hamil, 46\% responden yang kurang tahu berapa kali seharusnya melakukan pemeriksaan kehamilan selama hamil dan $8 \%$ responden yang tidak tahu berapa kali seharusnya melakukan pemeriksaan kehamilan selama hamil.

\section{Sikap}

Tabel 5. Distribusi responden berdasarkan pemeriksaan kehamilan bermanfaat bagi keselamatan ibu dan janin yang di kandungannya.

\begin{tabular}{clcc}
\hline No & Keterangan & N & \% \\
\hline 1 & Setuju & 50 & 100 \\
2 & Tidak setuju & 0 & 0 \\
\hline & Jumlah & 50 & 100 \\
\hline
\end{tabular}

Berdasarkan tabel lima, sebanyak 100\% responden setuju pemeriksaan kehamilan bermanfaat bagi ibu dan janin yang di kandungannya.

Tabel 6. Distribusi responden berdasarkan dengan memeriksakan kehamilan ibu dan bayi dapat terhindar dari komplikasi yang timbul sewaktu hamil atau melahirkan.

\begin{tabular}{cccc}
\hline No. & Keterangan & N & \% \\
\hline 1 & Setuju & 50 & 100 \\
2 & Tidak setuju & 0 & 0 \\
\hline & Jumlah & 50 & 100 \\
\hline
\end{tabular}

Berdasarkan tabel enam, sebanyak 100\% responden setuju dengan memeriksakan kehamilan ibu dan bayi dapat terhindar dari komplikasi yang timbul sewaktu hamil atau melahirkan.

Tabel 7. Distribusi responden berdasarkan setiap ibu hamil harus memeriksakan kehamilannya sekurang-kurangnya 4 kali selama kehamilan.

\begin{tabular}{cccc}
\hline No. & Keterangan & N & \% \\
\hline 1 & Setuju & 46 & 92 \\
2 & Tidak setuju & 4 & 8 \\
\hline & Jumlah & 50 & 100 \\
\hline
\end{tabular}

Berdasarkan tabel tujuh, sebanyak 92\% responden setuju dengan setiap ibu hamil harus memeriksakan kehamilannya sekurang-kurangnya empat kali selama kehamilan, $8 \%$ responden tidak setuju dengan setiap ibu hamil harus memeriksakan kehamilannya sekurang-kurangnya 4 kali selama kehamilan.

Tabel 8. Distribusi responden berdasarkan setiap ibu hamil harus memeriksakan kehamilan ketempat pelayanan kesehatan

\begin{tabular}{cccc}
\hline No. & Keterangan & N & \% \\
\hline 1 & Setuju & 50 & 100 \\
2 & Tidak setuju & 0 & 0 \\
\hline & Jumlah & 50 & 100 \\
\hline
\end{tabular}

Berdasarkan tabel delapan, sebanyak $100 \%$ responden setuju ibu hamil harus memeriksakan kehamilan ketempat pelayanan kesehatan.

\section{Tindakan}

Tabel 9. Distribusi responden berdasarkan ibu rutin melakukan pemeriksaan kehamilan ke pelayanan kesehatan selama hamil

\begin{tabular}{cccc}
\hline No. & Keterangan & $\mathbf{N}$ & $\mathbf{\%}$ \\
\hline 1 & Ya & 31 & 62 \\
2 & Tidak & 19 & 38 \\
\hline & Jumlah & 50 & 100 \\
\hline
\end{tabular}

Berdasarkan tabel sembilan, sebanyak $62 \%$ responden rutin melakukan pemeriksaan kehamilan ke pelayanan kesehatan selama hamil, 38\% responden tidak rutin melakukan pemeriksaan kehamilan ke pelayanan kesehatan selama hamil.

Tabel 10. Distribusi responden berdasarkan berapa kali ibu memeriksakan kehamilan selama hamil sesuai umur kehamilan.

\begin{tabular}{cccc}
\hline No. & Keterangan & $\mathbf{N}$ & $\mathbf{\%}$ \\
\hline 1 & $\geq 4$ kali & 25 & 50 \\
2 & $<4$ kali & 25 & 50 \\
\hline & Jumlah & 50 & 100 \\
\hline
\end{tabular}

Berdasarkan tabel 10, sebanyak 50\% responden lebih dari empat kali memerik- 
sakan kehamilan selama hamil sesuai umur kehamilan, 50\% responden kurang dari empat kali memeriksakan kehamilan selama hamil sesuai umur kehamilan.

Berdasarkan Tabel 11, sebanyak 52\% responden lebih dari empat kali memeriksakan kehamilan selama hamil terakhir, 48\% responden kurang dari empat kali memeriksakan kehamilan selama hamil terakhir.

Tabel 11. Distribusi responden berdasarkan berapa kali ibu memeriksakan kehamilan selama hamil terakhir.

\begin{tabular}{cccc}
\hline No. & Keterangan & N & \% \\
\hline 1 & $\geq 4$ kali & 26 & 52 \\
2 & $<4$ kali & 24 & 48 \\
\hline & Jumlah & 50 & 100 \\
\hline
\end{tabular}

Tabel 12. Distribusi responden berdasarkan dalam tiga bulan pertama berapa kali ibu memeriksakan kehamilan.

\begin{tabular}{cccc}
\hline No. & Keterangan & N & \% \\
\hline 1 & $\geq 1$ kali & 27 & 54 \\
2 & Tidak pernah & 23 & 46 \\
\hline & Jumlah & 50 & 100 \\
\hline
\end{tabular}

Berdasarkan tabel 12, sebanyak 54\% responden lebih dari satu kali dalam tiga bulan pertama memeriksakan kehamilan, $46 \%$ responden tidak pernah memeriksakan kehamilan.

Tabel 13. Distribusi responden berdasarkan dalam tiga bulan kedua berapa kali memeriksakan kehamilan.

\begin{tabular}{cccc}
\hline No. & Keterangan & $\mathbf{N}$ & $\mathbf{\%}$ \\
\hline 1 & $\geq 1$ kali & 42 & 84 \\
2 & Tidak pernah & 8 & 16 \\
\hline & Jumlah & 50 & 100 \\
\hline
\end{tabular}

Berdasarkan tabel 13, sebanyak 84\% responden lebih dari satu kali dalam tiga bulan kedua memeriksakan kehamilan, 16\% responden tidak pernah dalam tiga bulan kedua memeriksakan kehamilan.

Berdasarkan tabel 14, sebanyak 52\% responden lebih dari dua kali dalam tiga bulan terakhir memeriksakan kehamilan, $48 \%$ responden kurang dari kali dalam tiga bulan terakhir memeriksakan kehamilan.

Tabel 14. Distribusi responden berdasarkan dalam tiga bulan terakhir berapa kali ibu memeriksakan kehamilan.

\begin{tabular}{cccc}
\hline No. & Keterangan & N & \% \\
\hline 1 & $\geq 2$ kali & 26 & 52 \\
2 & $<2$ kali & 24 & 48 \\
\hline & Jumlah & 50 & 100 \\
\hline
\end{tabular}

\section{BAHASAN}

Berdasarkan hasil penelitian didapatkan Perilaku ibu hamil tentang Antenatal Care di Puskesmas Bahu, dari 50 responden yang melakukan ANC di puskesmas Bahu didapatkan bahwa seluruh responden mengetahui manfaat memeriksakan kehamilan ke pelayanan kesehatan sebesar (100\%). Responden yang mengetahui kapan sebaiknya pertama kali melakukan pemeriksaan kehamilan sebesar 36 orang (70\%) pada trimester I (satu sampai tiga bulan), sebesar 15 orang (30\%) pada trimester II (empat sampai enam bulan). Dari hasil penelitian dan wawancara dengan beberapa responden, pada umumnya responden mengetahui kapan sebaiknya melakukan pemeriksaan kehamilan pertama kali jauh lebih baik pemeriksakan kehamilan pada umur kehamilan trimester I (satu sampai tiga bulan). Responden mengetahui sebaiknya melakukan pemeriksaan kehamilan kepada dokter SpOg atau dokter umum sebesar 27 orang (54\%), sebesar 23 orang $(46 \%)$ mengetahui sebaiknya melakukan pemeriksaan kehamilan kepada bidan. Namun dari hasil wawancara, sebagian besar responden memilih memeriksakan kehamilan di puskesmas dikarenakan biaya pemeriksaan kehamilan di puskesmas jauh lebih terjangkau. Responden yang mendapatkan pelayanan yang diperoleh ketika memeriksakan kehamilan ke pelayanan kesehatan sebesar 50 orang (100\%).

Jumlah pemeriksaan kehamilan selama masa hamil yaitu sebanyak empat kali diketahui 23 orang (46\%). Dari uraian diatas, pengetahuan responden terhadap ANC dari setiap pertanyaan sudah baik. Hal ini menunjukan pengetahuan tentang pemerik- 
saan kehamilan mempengaruhi ibu hamil selama kehamilannya.

Responden yang setuju pemeriksaan kehamilan bermanfaat bagi keselamatan ibu dan janin yang di kandungannya sebesar 50 orang $(100 \%)$. Dan responden yang setuju dengan memeriksakan kehamilan ibu dan bayi dapat terhindar dari komplikasi yang timbul sewaktu melahirkan sebesar 50 orang (100\%). Responden yang setuju setiap ibu hamil harus memeriksakan kehamilannya sekurang-kurangnya lebih dari empat kali selama kehamilan sebesar 46 orang $(92 \%)$ dan responden yang tidak setuju sebesar empat orang (8\%). Dari uraian diatas sikap responden terhadap ANC dari setiap pertanyaan sudah baik. Sikap responden di wilayah kerja Puskesmas Bahu terhadap pemeriksaan kehamilan yang persentase terbesar setuju, dapat dikelompokkan responden dapat menerima dan mampu merespon. Hal ini berarti responden mempunyai kesiapan atau kesediaan untuk bertindak.

Tindakan dalam pemeriksaan kehamilan adalah pernah tidaknya responden melakukan pemeriksaan kehamilan. Responden yang rutin melakukan pemeriksaan kehamilan ke pelayanan kesehatan selama hamil sebesar 31 orang $(62 \%)$ dan responden yang tidak rutin melakukan pemeriksaan kehamilan selama hamil ke pelayanan kesehatan sebesar 19 orang (38\%). Responden yang tidak rutin melakukan pemeriksaan kehamilan umumnya pada umur kehamilan satu sampai tiga bulan, dimana responden menyatakan keterbatasan ekonomi dan juga bawaan hamil sehingga responden tidak rutin melakukan pemeriksaan kehamilan selama hamil.

Responden yang melakukan pemeriksaan kehamilan selama hamil sesuai umur kehamilan lebih dari empat kali sebesar 25 orang (50\%) dan kurang dari empat kali sebesar 25 orang $(50 \%)$. Responden yang melakukan kunjungan ANC responden selama hamil terakhir lebih dari empat kali sebesar 26 orang $(52 \%)$ dan kurang dari empat kali sebesar 24 orang (48\%). Responden yang melakukan kunjungan ANC dalam tiga bulan pertama sebesar 27 orang ( $54 \%$ ) dan responden yang tidak pernah melakukan kunjungan ANC selama tiga bulan pertama sebesar 23 orang (46\%). Responden yang melakukan kunjungan ANC dalam tiga bulan kedua selama hamil lebih dari satu kali sebesar 42 orang ( $84 \%$ ) dan responden yang tidak pernah melakukan kunjungan ANC dalam tiga bulan kedua sebesar delapan orang (16\%).

Dari uraian diatas tindakan responden terhadap ANC terhadap setiap pertanyaan sudah baik. Meskipun tindakan pemeriksaan kehamilan responden cukup tinggi, namun tidak seluruhnya melakukan pemeriksaan kehamilan tersebut secara lengkap sesuai dengan aturan yang ada.

\section{SIMPULAN DAN SARAN}

Pengetahuan, sikap, dan tindakan yang dimiliki responden yang melakukan ANC di puskesmas Bahu sudah cukup baik, hal ini dapat dilihat dari responden yang seluruhnya tahu manfaat ANC.

Dari hasil penelitian ini dapat disarankan kepada pemerintah untuk mendekatkan pelayanan pemeriksaan kehamilan dengan menempatkan petugas di daerah yang sulit di jangkau khususnya posyandu, sehingga jangkauan (akses) masyarakat dapat ditingkatkan dan cakupan program dapat dicapai. Dan perlu peningkatan kegiatan penyuluhan kepada masyarakat oleh tenaga kesehatan tentang pentingnya dilakukan pemeriksaan kehamilan sesuai dengan umur kehamilannya sebagai upaya menurunkan angka kematian ibu.

\section{DAFTAR PUSTAKA}

1. Royston E. Pencegahan kematian ibu hamil. Jakarta: Binarupa Aksara, 2010.

2. Dinas Kesehatan Kota Manado. Profil Kesehatan Pemerintah Kota Manado, 2010.

3. Mochtar R. Sinopsis Obstetri jilid 1 (Edisi Kedua). Jakarta: EGC, 1998.

4. Angka kematian Ibu dan Bayi Masih Tinggi [homepage on the Internet]. Nodate [cited 2011 Nov 10]. Available from: http://www.doctoc.com/docs/6848994/ 